\title{
Vahva puheenvuoro globaalia vastuuta tähdentävän kansansivistyksen puolesta
}

Seppo Niemelä (2011). Sivistyminen. Sivistystarve, -pedagogiikka ja -politiikka pohjoismaisessa kansansivistystraditiossa. Snellman-instituutin A-sarja 25/2011. Kansanvalistusseura ja Snellman-instituutti.

FT Seppo Niemelän väitöskirja on merkittävä tutkimus pohjoismaisen kansansivistyksen lähtökohtien, aatehistoriallisten juurien ja nykyajassa elähdyttävien merkitysten tavoittamiseksi. Niemelän kunnianhimoisena tarkoituksena on ollut kehittää yleiskuva sivistymisestä ja sitä tukevasta sivistyspedagogiikasta ja vapaan sivistystyön edellytyksiä luovasta sivistyspolitiikasta. Tämä tarkoitus on vaatinut keskustelua sekä pohjoismaisen kansansivistyksen aatehistorian että sivistysteoreettisen ja sosiaalipedagogisen tutkimuksen kanssa. Niemelän tutkimuksen viimekätisenä tavoitteena on ollut vastata siihen, miten vapaa kansansivistystyö kohtaa nykyajan sivistystarpeen.

Väitöskirja on tehty sosiaalipedagogiikan alalle, mutta siinä leikkaavat myös filosofian, aateja oppihistorian sekä kasvatus- ja aikuiskasvatustieteiden näkökulmat. Tutkimuksen monitasoiseksi jakautuva kenttä vaatii välttämättä monitieteisyyttä ja tutkijan, joka hallitsee riittävällä varmuudella tutkimusta leikkaavat tiedonalat. Niemelän tutkimustehtävät ja -tavoitteet ovat laajuudessaan ja monikerroksisuudessaan riski ja ansio samanaikaisesti. Tutkimuksen metodologiset ja metodiset kysymykset ovat erityisen vaativia. Lähestyäkö tutkimuskenttää perinteisen historiantutkimuksen keinoin? Millä kriteereillä valita tutkimuksen edustavat kohteet? Miten luoda luotettavuutta ja uskottavuutta kertomukseen, joka hakee vastauksia nykypäivän probleemeihin menneisyydestä? Seppo Niemelän vastaus on gadamerilaisiin periaatteisiin sitoutunut hermeneuttinen traditiontutkimus. Lähtökohtana on ajatus, että menneisyys on läsnä nykyhetkessämme, ja hermeneutiikan keinoin voimme ymmärtäen tavoittaa menneisyydestä kumpuavien ideoiden ja motiivien vaikutushistorian omassa ajassamme.

\section{GRUNDTVIG, OLSON, ALKIO}

Pohjoismaista kansansivistyksen traditiota tutkimuksessa edustavat kansanopistolaitoksen isä, tanskalainen Nikolai Grundtvig (17831872), ruotsalainen opintokerhotoiminnan kehittäjä Oscar Olsson (1877-1950) ja suomalainen nuorisoseuraliikkeen ideologi ja kasvatusajattelija Santeri Alkio (1862-1930). Tutkimuksen aikaperspektiivi on laaja. Rajautuminen yksinomaan pohjoismaisen kansansivistyksen kontekstiin ja vaikutusyhteyksiin vaatii jo lähes parin sadan vuoden näköalan.
Pohjoismaisen sivistysajattelun taustoittaminen saksalaisesta valistusfilosofiasta asettaa ajallisen jänteen aina 1700-luvulle saakka. Seppo Niemelä ei ole kaihtanut aiheensa kompleksisuutta. Tutkimukselleen asettamat tarkoitukset ovat velvoittaneet Niemelän kontekstoimaan työnsä saksalaiseen valistusfilosofiaan ja siitä juontuvaan sivistysteoreettiseen kasvatusajatteluun. Hän on tulkinnut Grundtvigin, Olssonin ja Alkion kansansivistysajattelua aikansa aatevirtausten ja niiden taustalla olevien suurten kertomusten, kristinuskon ja valistusfilosofian, sekä näiden jännitteisen suhteen, yhteydessä.

Kant, Herder, Hegel ja Snellman ovat keskeisiä taustahahmoja saksalaisten sivistysteoreetikkojen ohella. Tutkijalta edellytetään vahvaa filosofista perussivistystä, sivistysteorian ja -pedagogiikan tuntemusta ja kypsää tieteenfilosofista ja metodologista ymmärtämystä, jotta tutkimuksen eri tasojen välisestä dialektiikasta kehkeytyisi sisäisesti johdonmukainen, luotettava ja uutta tietoa tuottava kontribuutio.

Seppo Niemelän väitöskirja on kirjoittajansa näkemyksellisyyttä ja oppineisuutta osoittava filosofinen puheenvuoro. On kuiten- 
kin syytä korostaa, että Niemelän pääasiana ei ole ollut filosofien ja filosofisten oppisuuntien filologis-kriittinen tutkimus, vaan kansansivistystraditioiden yleislinjojen ja yleisimpien periaatteiden osoittaminen. Tutkimuksen laaja-alaisuus ja Niemelän valitsema tutkimustapa näkyvät myös kerronnan tavassa. Ajattelu on kirkasta ja moitteetonta, mutta usein myös referoivaa ja selostavaa.

Tutkimuksen metodologisten lähtökohtien ja tutkimustehtävien valossa Niemelän tyylivalinta on kuitenkin ymmärrettävä. Alun perinkään ei ole ollut tarkoitus etsiä ristiriitaisuuksia, katkoksia ja murtumia kansansivistysajattelijoiden keskinäissuhteista eikä heidän suhteestaan taustafilosofioihinsa. Toki tutkimuksen intentiot haastavat pohtimaan metodologisten sitoumusten merkitystä ja eritoten sitä, millaisia tulkintaeroja olisi seurannut yleisen historiantutkimuksen, hermeneuttisen traditiontutkimuksen ja kriittisen historiantutkimuksen tietoteoreettista painotuseroista. Tutkimusraportin sinänsä toimiva perusrakenne noudattaa Niemelän kuvaamia hermeneutiikan periaatteita, mutta paikoin jää lukijan intuition varaan oivaltaa, miten hermeneuttiset askeleet etenevät tutkimuksen eri vaiheissa.

Tutkimustehtävän laajuus ja moniaineksisuus ovat ehkä syynä siihen, että välillä on vaikeaa hahmottaa, miten eri juonteista kehkeytyy yhtenäinen kertomus, siis miten horisonttien sulautuminen tapahtuu. Niemelä palaa joihinkin ajatuskulkuihin useita kertoja ennen varsinaista applikaatiovaihetta, mikä osaltaan kysyy lukijalta malttia hermeneuttisen polun seuraamisessa. Toisaalta on myönnettävä, että gadamerilainen hermeneutiikka sallii tutkijalle vapauksia, koska sitä ei ole alun perinkään tarkoitettu metodiopiksi tai tiukasti noudatettavaksi kaanoniksi. Hermeneutiikan idean Seppo Niemelä on ymmärtänyt mallikelpoisesti.

Seppo Niemelän laaja lukeneisuus ja oppineisuus ovat mahdollistaneet sen, että moniaineksisista lähtökohdista on rakentunut puhutteleva synteesi. Sivistysteoreettiset ja sosiaalipedagogiset tulkintansa Niemelä on omaksunut pääosin Pauli Siljanderin ja Juha Hämäläisen tuotannosta. Hän on kuitenkin rakentanut lähteistään ja muusta oppimastaan "oman päänsä”. Väitöskirjan sivuilta paljastuu syvällinen ja näkemyksellinen kasvatusajattelija, josta löytyy sekä "ahlmanilaisuutta" että kriittistä pedagogiikkaa: elinikäistä oppimista hallitseva välineellisyys ja oppimispsykologiaksi ja osaamisretoriikaksi redusoitunut kasvatustiede saavat ansaittua kritiikkiä.

\section{JOHN LOCKESTA MODERNIIN PEDAGOGIIKKAAN}

Vaikka työ olisi laajakin, siinä ei voi kattaa kaikkea. Väitöskirjallaan Niemelä on luonut mainion perustan kansansivistyshistorian jatkotutkimuksille, joiden soisin suuntautuvan myös saksalaisen perinteen ulkopuolelle. Siljanderiin viitaten Niemelä kuvaa kansansivistyksen painopisteiden muutosten yhteyttä kasvatusajattelun samanaikaiseen korvautumiseen oppimispsykologisesti painottuneella oppimis- ja osaamisretoriikalla. Oppimispsykologinen käänne on alkuperältään anglo-amerikkalainen, muttei riippumaton eurooppalaisista virtauksista. Tero Autio ja äskettäin väitellyt Sauli Salmela ovat osoittaneet tutkimuksissaan, että John Locke on keskeinen henkilö modernissa pedagogiikassa ja opetussuunnitelmateoreettisessa ajattelussa: brittiläisen empirismin lisäksi sekä saksalainen Bildung-perinne että amerikkalainen kasvatusfilosofia ja psyko- 


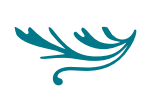

logisoitunut opetussuunnitelmaajattelu ovat ammentaneet ideoitaan Locken filosofiasta. Tässä on vihje mahdolliselle jatkotutkimukselle.

Kansansivistyksen tietäjänä ja taitajana Niemelä on kiistaton ammattimies, jonka työn tähänastinen intellektuaalinen yhteenveto on nyt saatu kansien väliin. On oikein ja sallittua, että kokenut ammattilainen pyrkii laajaan kokonaisnäkemykseen väitöskirjassaan. Maineteoksi riittäisi yksinomaan jo Grundtvigin, Olssonin ja Alkion perusteellinen, yhtäaikainen tarkastelu, jonka ansiosta olemme saaneet kokonaisesityksen pohjoismaisesta sivistysajattelusta ja -työstä. Niemelän ansiona on mainittava erityisesti, että hänen väitöskirjansa on ensimmäinen suomenkielinen esitys Oscar Olssonin elämäntyöstä.

Niemelä on ottanut tutkimuksessaan tietoisen riskin, sillä sivistystarpeen, -pedagogiikan ja -politiikan yhtäaikainen tarkastelu historiasta tulkiten, mutta nykyaikaan tähdäten on poikkeuksellisen vaativa ja riskialtis tehtävä. Vaikka Niemelän työn laaja-alaisuus näkyy paikka paikoin pienenä epäkoherenssina, se on myös väitöskirjan ehdoton ansio.
Kaikissa merkittävissä teksteissä on intohimoa, rohkeutta ja näkemyksellisyyttä, joka ylittää tekstin sisäiset "kauneusvirheet". Niin on myös Seppo Niemelän väitöskirjassa. Seppo Niemelän väitöskirja on kokonaiskuvaltaan laadukas ja erinomaisella suomen kielellä kirjoitettu tutkimus, joka jää kiertämättömäksi maamerkiksi myöhemmille sivistyksen ja sivistyspolitiikan tutkijoille.

\section{KANSALAISYHTEISKUNTA JA SIVISTYSPÄÄOMA}

Seppo Niemelän väitöskirjatutkimus ammentaa historiasta, mutta sen tarkoite on omassa ajassamme. Niemelän lähimmät kansainväliset sukulaissielut ovat Ove Korsgaard, Robert Putnam ja Berndt Gustavsson. Niemelä argumentoi erityisen ansiokkaasti aktiivisen kansalaisyhteiskunnan ja globaalista vastuusta tietoisen sivistyspääoman puolesta keskustellessaan Korsgaardin ja Putnamin ajatusten kanssa. Niemelä nostaa työnsä loppupuolella esille suuret huolenaiheet, jotka eivät enää pysyttäydy yksittäisten kansallisvaltioiden ja yhteiskuntien kehyksissä. Siten Niemelän rehabilitoiman sivistysprojektin ei pidä rajautua pelkästään kansalliseksi kysymykseksi, vaan näkökulman on laajennuttava globaaliksi.

Niemelän esittämiä suurimpia huolenaiheita ovat eriarvoistuminen, syrjäytymisriskit, marginalisoituminen, ääriajatusten esiinnousu ja luonnon ekologinen kriisiytyminen. Kysymys on sekä demokratian ylläpitämisestä ja kehittämisestä että elämän ekologisten perusteiden pelastamisesta.

Seuraava suuri kertomuksemme on ekologinen sivistysprojekti. Ekologisen vastuuntunteen herättämisestä tulee kasvatuksen kollektiivinen tehtävä. Tarvitaan viisasta poliittista päätöksentekoa ja ohjausta, mutta myös ennen kaikkea kasvatusta ja sivistystyötä, joka luo edellytyksiä ekologisesti kestävän, inhimillisen elämän säilymiselle. Seppo Niemelän perustelemalle sosiaalipedagogisesti virittyneelle ekologiselle sivistysajattelulle on totisesti tarvetta.

Veli-Matti Värri

professori

kasvatusfilosofia ja

luokanopettajakoulutus,

Tampereen yliopisto

dosentti (eettinen kasvatus),

Maanpuolustuskorkeakoulu 